\title{
Memória hierofânica do catolicismo popular sertanejo e a sacralização da Serra do Horto, em Juazeiro do Norte - CE
}

Hierophant memory of backcountry popular Catholicism and the sacralization of Serra do Horto, in Juazeiro do Norte - CE

Paulo Wendell Alves de Oliveira $₫$ (ID

Departamento de Geociências, Centro de Humanidades, Universidade Regional do Cariri, Crato, Ceará, Brasil

Recebido (Received): 16/09/2020

*E-mail para correspondência: paulowendell@bol.com.br

Resumo: A geografia da religião é um campo que nos permite diversas formas de abordagem do fenômeno religioso e sua relação com o espaço geográfico. A memória hierofânica constitui-se de uma base de leitura para a compreensão da constituição de grupos religiosos diversos sendo feita, especificamente neste trabalho, uma análise sobre o processo de espacialização do movimento do catolicismo popular sertanejo em Juazeiro do Norte, Ceará, tomando por recorte espacial a Serra do Horto, local de grande devoção que marca a relação do sagrado com esse grupo religioso. Tomamos a paisagem do sagrado e os ritos realizados pelos sujeitos como documentos que nos ajudam a compreender a constituição do próprio grupo e as formas de espacialização da crença que possuem e que marcam seu sistema simbólico. Ademais, associamos a esses documentos do sagrado a oralidade dos sujeitos pertencentes a essa crença, permitindo uma interpretação da forma simbólica do catolicismo popular sertanejo. Percebe-se que, em Juazeiro do Norte, dada a figura do Padre Cícero, ao ato hierofânico lá ocorrido e a paisagem existente nesse espaço, é permitida uma coerência de narrativa assumida pelo grupo em busca da "terra sem males", que é uma das principais características que se associa a esse grupo religioso e constituiu o processo de espacialização simbólica nesse território, assumindo-o como sagrado ou sendo a própria "terra sem males".

Palavras chave: Sistema Simbólico; Sagrado; Paisagem; Movimento Religioso.

Abstract: The geography of religion is a field that allows us to approach the religious phenomenon and its relation with the geographic space. The hierophant memory constitutes a reading base for understanding the constitution of different religious groups, being made an analysis, specifically in this work, about the process of spatialization of the movement of backcountry popular Catholicism in Juazeiro do Norte, Ceará, taking as a spatial cutout the Serra do Horto, a place of great devotion that marks the relation of the sacred with this religious group. We took the landscape of the sacred and the rites performed by the subjects as documents that help us to understand the constitution of the group itself and the spatialization forms of the belief that they have and that mark their symbolic system. In addition, we associated to these documents of the sacred the orality of the subjects that belong to this belief, allowing an interpretation of the symbolic form of backcountry popular Catholicism. It can be seen that, in Juazeiro do Norte, given the figure of Father Cícero (Padre Cícero), the hierophant act that took place there and the landscape in that space, it is allowed a coherent narrative assumed by the group in search of the "land without evils", which is one of the main characteristics associated with this religious group and constituted the process of symbolic spatialization in that territory, assuming it as sacred or being the "land without evils" itself.

Kaywords: Symbolic System; Sacred; Landscape; Religious Movement.

\section{Introdução}

O catolicismo popular sertanejo se constituiu através do processo de apropriação do território vinculado a colonização do Brasil, o qual se efetivou tendo o Estado (Coroa Portuguesa) e a Igreja (Igreja Católica Europeia) como os principais agentes desse processo de apropriação do território. A ligação desses dois agentes colonizadores, dado através do sistema de padroado que perdurou no território brasileiro, apresentou- 
se como base da constituição do catolicismo popular sertanejo, tendo em vista que só possuíam direito a terras aqueles sujeitos que vinculavam-se a fé oficial do Estado.

Ligado a esse processo surge o catolicismo popular sertanejo e todo o sistema de crenças que a ele está ligado. O catolicismo popular sertanejo dá-se em um processo de ressignificação existente no sertão da caatinga, território vinculado ao processo de expansão do gado para o interior da colônia.

Destaca-se que a forma de catequização que perdurou na região do sertão da caatinga foi realizada pelos próprios leigos, ou seja, o povo catequizava o povo, permitindo a manutenção de vários símbolos, ritos, crenças de outras matrizes religiosas, dado que os sujeitos que foram catequizados nesse processo eram escravos alforriados, nativos locais que habitavam essas regiões e sujeitos sem posses que passaram a habitar esses territórios. O que se percebem é uma justaposição de crenças que se manteve forte no catolicismo popular sertanejo, mantido pela memória hierofânica do grupo religioso, vinculando-se principalmente a crença da busca pela "terra sem males", ressignificando a histórias bíblicas para a realidade social vivida pelo povo sertanejo em diferentes épocas, principalmente na vinda de um "Messias" (um salvador) que conduziria o povo a uma terra prometida.

Tomando por base de estudo o grupo religioso do catolicismo popular sertanejo, busca-se compreender como a memória hierofânica desse grupo religioso produz uma espacialização na localidade de Juazeiro do Norte-CE, ressignificando paisagens e lugares, através de seus conjuntos de crenças, símbolos e ritos, na busca desse espaço como a "terra sem males" e da transfiguração do Padre Cícero como um "Messias" sertanejo.

Para chegarmos a essa concepção, tomamos por base as construções teóricas de Cassirer (2004), que nos aponta como princípio para a compreensão do fenômeno religioso, não o tomar pela sua materialidade em si ou simplesmente pela sua forma de espacialidade, mas compreender a religião como uma forma de expressão simbólica de um dado grupo religioso. A explicação do universo religioso não deve ter como ponto de partida as questões meramente de concepções da religião, ou seja, não como mera substância, mas deve-se entender sua forma, como se desenvolve no contexto cultural de determinado grupo, de modo que alcançaremos, com maior força, o objetivo de analisar os fenômenos da religião.

Foi com este intuito que construímos uma linha de raciocínio sobre a constituição de uma forma simbólica de catolicismo, aqui por nós tratado por catolicismo popular sertanejo. Não desenvolvemos uma análise da substância religiosa que reveste o sistema de crenças do grupo, mas uma construção teórica baseada no processo de constituição e espacialização do catolicismo popular, ressaltando a justaposição (alguns autores utilizam-se do termo sincretismo religioso para descrever tal contexto) de sistemas culturais que permeiam desde nativos, negros, portugueses e missionários inseridos num âmbito de desenvolvimento da economia-mundo no qual foram tratadas as diferentes perspectivas, consolidando-se em uma nova forma simbólica, o catolicismo popular sertanejo.

\section{Memória hierofânica para a compreensão do universo simbólico do catolicismo popular sertanejo}

$\mathrm{O}$ que nos chama a atenção para pensar a relação entre o catolicismo popular sertanejo e o Juazeiro do Norte, dá-se pelos fenômenos religiosos que aconteceram em distintos momentos desta localidade e as figuras que a ela estão ligadas.

Cabe, no entanto, destacar que o sertão da caatinga já possuía as experiências de sujeitos que se sobressaíram como líderes desse movimento religioso (os chamados "Messias"), pela sensibilidade que possuíam com a população sertaneja do sofrimento em decorrência do contexto social da localidade, acometida pela fome, por doenças e por todas as calamidades sociais das quais eram sujeitados.

No caso de Juazeiro do Norte, o Pe. Cícero se sobressaiu como uma figura de líder carismático do movimento religioso ocorrido em Juazeiro do Norte, principalmente pelo propagado "milagre da hóstia", ocorrido no ano de 1889 e que mudou a realidade da localidade. Nesse episódio uma beata, de nome Maria de Araújo, ao receber a hóstia em sua boca esta teria transmutado-se no sangue de Cristo.

A hierofania que ocorreu em 1889 em Juazeiro só produziu efeitos para a coletividade de crentes do catolicismo popular sertanejo porque era uma narrativa aceita por ela, os sistemas de linguagens que relatam os fatos extraordinários produzem sentido para o corpo coletivo do grupo religioso. O Padre, a Beata e o Espaço-Tempo da localidade foram transmutados em algo extraordinário, não pelo fenômeno em si, mas pela narrativa que assumiu na forma simbólica existente do grupo do catolicismo popular sertanejo validando o fenômeno para os seus fiéis. 
[...] O conhecimento humano é por sua própria natureza um conhecimento simbólico. É este traço que caracteriza tanto a sua força como as suas limitações. E, para o pensamento simbólico, é indispensável fazer uma distinção clara entre o real e o possível, entre as coisas reais e ideais. Um símbolo não tem existência real como parte do mundo físico; tem um "sentido". (CASSIRER, 2012, pp. 96-97).

Seu sistema simbólico, dada a forma que assumiu no processo de desenvolvimento pelo qual passou, tornou aquele fenômeno inteligível para uma coletividade que passou a aceitar a manifestação do sagrado que ocorreu na região. Se o grupo fosse outro, se tivesse sido consolidado o processo de romanização provavelmente não produziria o mesmo impacto, como o que foi visto e que ainda é vivido em Juazeiro do Norte pelo grupo religioso do catolicismo popular sertanejo. Sem a compreensão da forma cultural do grupo, ficaríamos encerrados apenas na análise da substância do fenômeno, perdendo a sua dimensão funcional.

No entanto, pela concepção da forma existente no catolicismo popular sertanejo, nos é possível observar a espacialização de práticas culturais do mundo simbólico desse grupo a partir de suas crenças, signos e ritos que se manifestam no espaço sagrado de Juazeiro do Norte, tornando-se verdadeiros documentos de memória hierofânica do fenômeno religioso do catolicismo popular sertanejo.

Nessa perspectiva de uma análise fundamentada na geografia da religião, não nos limitamos a compreender as formas espaciais do fenômeno religioso, mas avançamos no sentido de entender as estruturas estruturantes do fenômeno religioso (GIL FILHO, 2007) ligado ao catolicismo popular sertanejo. As formas materiais, nessa concepção, nos têm valor de análise no sentido em que se apresentam como documentos para a compreensão não só do fenômeno religioso que se registra em Juazeiro do Norte, mas de uma chave de leitura do próprio universo simbólico do catolicismo popular sertanejo, com base em sua forma cultural, pelo sistema simbólico religioso o qual se reconhece o grupo.

Durkheim (2008), ao analisar as formas elementares de vida religiosa, acredita que não devemos procurar as explicações sobre os mitos no mundo físico, posto que não estão encerrados nesse universo. Devemos, no entanto, buscar suas explicações nas projeções que são realizadas a partir da vida social do grupo religioso. Esse aspecto é bastante presente na hierofania que ocorreu em Juazeiro do Norte. O que se fazia, por parte do grupo, ao aceitar aquele fenômeno como transcendental, de caráter divino, foi a possibilidade de uma nova vida, não somente espiritual, mas de superar as dificuldades impostas no universo social do período. A mesma linha de raciocínio pode ser desenvolvida em Canudos e no Caldeirão do Beato José Lourenço.

Sob esse aspecto da projeção da vida social, como forma para a compreensão do mito, acrescenta Cassirer (2012, pp. 135-136): “[...] O verdadeiro substrato do mito não é um substrato de pensamento, mas de sentimento [...]. Sua coerência, porém, depende muito mais de unidade de pensamento do que de regras lógicas".

Partindo da memória hierofânica como base de análise, permite entender a forma do catolicismo popular sertanejo, não só em sua manifestação espacial, mas desde a sua própria estrutura estruturante. A hierofania de Juazeiro do Norte, transfigurada no "milagre da hóstia", nos aparece como um documento para ler a forma cultural do catolicismo popular sertanejo que produziu, em seu sistema simbólico, através da linguagem, a ligação de um evento da busca pela "terra sem males", ressignificando a própria lógica do catolicismo europeu. A crença na vinda de um Messias, de tempos em tempos, em um ritmo cíclico, está estruturada no imaginário simbólico dos crentes do catolicismo popular sertanejo, justamente por essa condição está presente nas crenças que se justaposicionam-se para constituir esse movimento religioso (como nas religiões de matrizes africanas e dos nativos americanos que habitavam a porção desse território), e é isso que faz com que atestem para a veracidade do fenômeno, independentemente da posição assumida pela Igreja Católica. A força desse fenômeno pode ser vista nos tempos e espaços sagrados que marcam a paisagem de Juazeiro do Norte.

Assim, temos na análise da memória hierofânica a materialidade espacial surgindo como um documento para compreender um sistema religioso, aqui tratado como catolicismo popular sertanejo. Nos é cabível acrescentar que o espaço em si não possuí memória, esta se realiza através dos sujeitos. No contexto do catolicismo popular sertanejo, vincula-se aos que creem e participam do mesmo grupo religioso. Sendo assim é possível conciliar a compreensão da materialidade aos documentos que reportem a hierofania, havendo ainda um terceiro aspecto, a própria oralidade dos sujeitos, suas narrativas e histórias de vida que apresentam toda a força que o sistema simbólico, o qual estão inseridos, exerce sobre eles.

Ao trabalhar com a oralidade, desenvolveu-se entrevistas semiestruturadas abordando a vivência de sujeitos do grupo religioso do catolicismo popular sertanejo, quais aspectos de suas histórias de vida dialogam com a narrativa assumida pelo grupo religioso e permitem que esses sujeitos espacializem suas práticas religiosas na localidade de Juazeiro do Norte, compreendendo-a como a própria "terra sem males". 
No decorrer do trabalho será apresentado trechos de falas de dois sujeitos, pertencente ao grupo social do catolicismo popular sertanejo, que refletem a narrativa simbólica assumida pelos sujeitos pertencentes a esse grupo.

Em vista disso, desenvolvemos nosso interesse pela hierofania e pelo espaço sagrado existente em Juazeiro do Norte. O que busca-se analisar não é o fenômeno em si, nem a materialidade espacial sagrada existente na localidade - entende-se que já há valiosas contribuições nesse sentido; o que se quer é partir dessa materialidade para avançar na compreensão da forma simbólica religiosa do catolicismo popular sertanejo e sua forma de espacialização, assim, esses lugares sagrados que irradiam diversas práticas devocionais nos abrem um campo de entendimento da geografia da religião para a compreensão da forma simbólica religiosa do catolicismo popular sertanejo.

Destarte, pretende-se apresentar a materialidade espacial dos lugares sagrados e as práticas devocionais praticadas como formas narrativas, documentos que constituem não a memória hierofânica de Juazeiro do Norte, mas a memória hierofânica do catolicismo popular sertanejo espacializada em Juazeiro do Norte. Entende-se a materialidade sagrada, constituindo parte da narrativa do universo simbólico do catolicismo popular sertanejo a partir das práticas que ali se espacializam, mas que não se encerram nesse lugar, sendo reproduzidas em outros espaços sagrados que sejam assumidos como valor transcendental para a coletividade do grupo religioso do catolicismo popular sertanejo. Também nos interessa e defende-se que constituem a memória hierofânica do grupo religioso do catolicismo popular sertanejo a oralidade dos sujeitos que estão inseridos neste universo simbólico religioso.

\section{A memória hierofânica para além dos espaços consagrados}

Intentamos agora por desenvolver uma análise da espacialização do sagrado em Juazeiro do Norte. Como destacamos anteriormente, nossa percepção sobre a questão espacial do sagrado é vista como um documento que permite compreender o universo simbólico do catolicismo popular sertanejo. Não analisamos a espacialidade do fenômeno em si mesmo, mas o que se pretende é partir do espaço sagrado para a espacialização das práticas simbólicas, ritos, signos e crenças, que só ocorrem pela coerência narrativa que esta produz para uma coletividade, assim, é possível analisá-las para compreender a forma estruturante do catolicismo popular sertanejo tomando por base alguns lugares sagrados existentes na hierópolis de Juazeiro do Norte. Nesse princípio, lembramos os dizeres de Merleau-Ponty (2011, p. 328) sobre o espaço:

[...] O espaço não é o ambiente (real ou lógico) em que as coisas se dispõem, mas o ambiente pelo qual a posição das coisas se torna possível. Quer dizer, em lugar de imaginálo como uma espécie de éter no qual todas as coisas mergulham, ou de concebê-lo abstratamente com um caráter, que lhes seja comum, devemos pensá-lo como a potência universal de suas conexões.

Sobre este aspecto, Cassirer (2004; 2012), dialogando com as ideias expostas de Merleau-Ponty, observa que a compreensão espacial do sagrado não se dá pela análise do espaço como ambiente das coisas, mas do espaço enquanto fonte que pode revelar toda a força de um fenômeno para o coletivo de sujeitos. São os sujeitos que passam a suportar e a interiorizar pela narrativa na qual se reconhecem, dado o sistema cultural simbólico do qual participam, tornando o espaço inteligível e dando coerência ao fenômeno - isto é o que Merleau-Ponty (2011) traduz como a passagem do "Espaço espacializado para espaço espacializante".

A análise que foi realizada neste trabalho tomou por recorte espacial a chamada Serra do Horto, em Juazeiro do Norte, sendo este um dos lugares de maior expressividade de manifestações dos sistemas de crenças, símbolos, signos e ritos do universo religioso do catolicismo popular sertanejo. A concepção de lugares sagrados é apresentada por Costa $(2011$, p. 32) da seguinte forma: "Através da sacralização e consagração, a religião cria a ideia de espaço sagrado. Templos, igrejas, cemitérios, montanhas, cidadessantuário são considerados lugares sagrados".

A Serra do Horto (Figura 1), constitui-se de um espaço de ressignificação apresentada na narrativa do grupo religioso onde o espaço foi transfigurado pela concepção mítica do grupo, do surgimento de um novo "Messias" e de uma nova "Terra Prometida" ou "Terra Sem Males"; Os lugares analisados foram: o Monumento do Padre Cícero, local de maior visitação dos romeiros, onde se expressa fortemente o sistemas de crenças e ritos que compõem o universo simbólico religioso do catolicismo popular sertanejo; o Casarão do Padre Cícero, onde existem relíquias do Padre, que traz toda a força do grupo religioso pelas formas materializadas do sistema de crenças, no depósito dos ex-votos e, por fim, o Santo Sepulcro, também vinculado à mística da "Terra Sem Males" com base na concepção religiosa do grupo. 


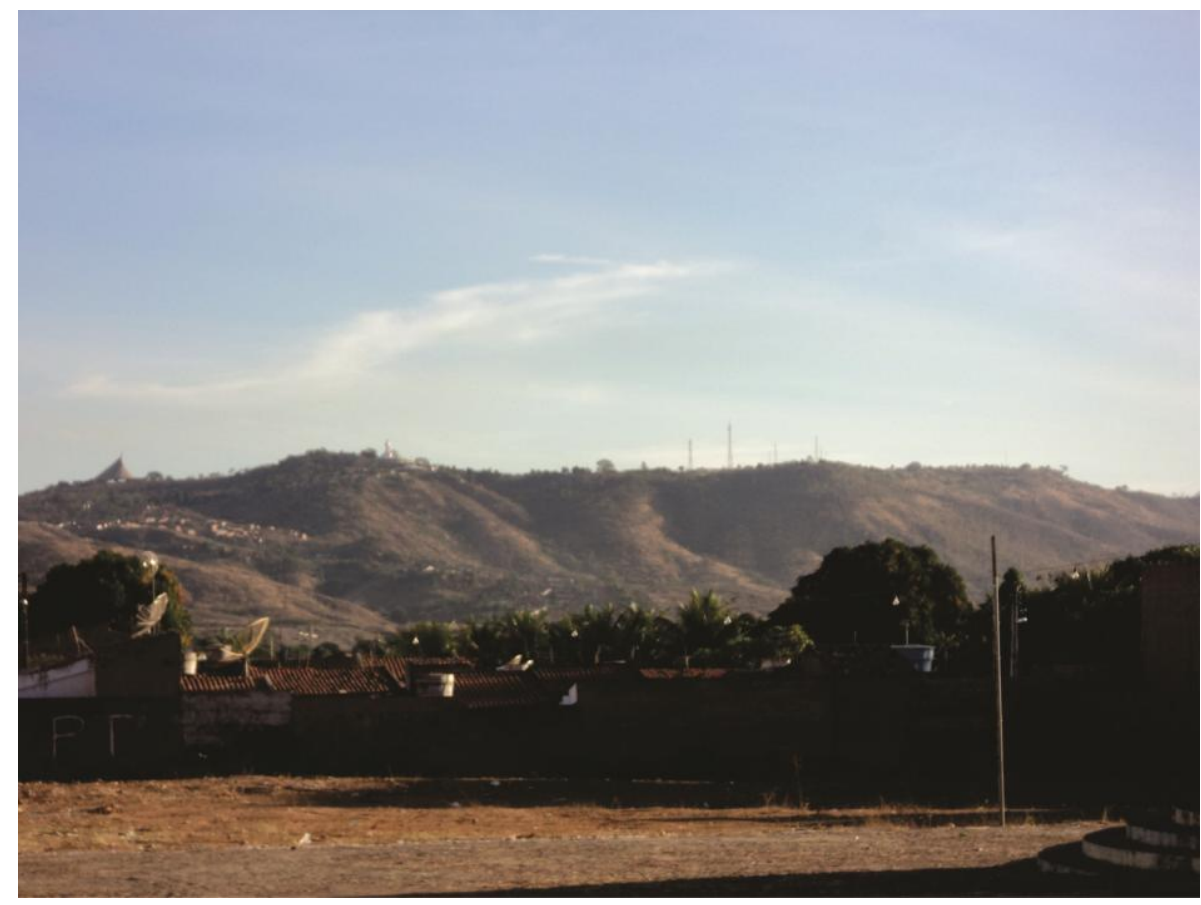

Figura 1: Serra do Horto. Fonte: Acervo do autor, 2018.

A Serra do Horto em Juazeiro do Norte, antes conhecida como Serra do Catolé, tem grande representatividade simbólica para o universo do Catolicismo Popular Sertanejo que visita a região. Este espaço se constitui de práticas devocionais vinculadas à concepção de mundo que os sujeitos relacionados a esse grupo realizam do sagrado.

Como destacamos no tocante ao messianismo, tal aspecto simbólico do catolicismo popular pauta-se na crença da vinda de um messias, de tempos em tempos, que vai conduzir o povo à "Terra Santa". Essa narrativa que é desenvolvida no catolicismo popular sertanejo, que faz com que os sujeitos pertencentes a esse grupo aceitem essa crença, está ligado ao contexto de atuação da Igreja Católica no período colonialista.

O que podemos pontuar é o contexto no qual se desenvolveu o processo de catequização do universo sertanejo e dos grupos que dele fazem parte (nativos, negros, camponeses, imigrantes, etc.), entregues à própria sorte em uma conjuntura na qual se prosperavam as ações do capitalismo mercantil propagando o poder da Coroa e da Igreja. O sertanejo vislumbrava dias melhores, intentando fugir das calamidades que os afligiam. Destacamos que as áreas longínquas dos centros econômicos não tinham uma estrutura eclesiástica, tendo sua formação religiosa realizada por leigos que viviam o mesmo universo penoso.

A atuação do Padre Ibiapina foi de fundamental importância para a disseminação do universo simbólico do catolicismo popular sertanejo na região do Cariri cearense. O que se nota no universo do catolicismo popular sertanejo é a busca de alternativas para sua resistência e para sua própria sobrevivência. Desse modo, passou a apropriar-se do discurso religioso católico do período colonial, de embate entre Deus e o demônio, a promessa da terra onde não haveria mais sofrimento. Ao apropriar-se dessa narrativa simbólica o catolicismo popular sertanejo, transpassa essa crença a vinda do Messias que iria se apresentar para salvar os sertanejos dos males que viviam, daí onde se insere o Padre Cícero e Juazeiro do Norte.

Cabe destacar que as matrizes religiosas que se justapõe na constituição do Catolicismo Popular Sertanejo, já guardavam a crença de líderes salvadores, com poderes excepcionais, capazes de permitir a esses povos vencerem as calamidades de que tinham de suportar. Esse aspecto pode ser visto através de cultos a divindades, nas diferentes concepções religiosas de matrizes africanas, a crença de um pajé, líder com poderes excepcionais, existente na crença dos povos nativos ou os próprios cultos a natureza. Todo esse universo é transfigurado e ressignificado na interpretação do catolicismo europeu, na catequização do "povo pelo povo", mantendo e justapondo essas crenças para vencer os males aos quais estavam sujeitos.

O nome Serra do Horto surge pela ressignificação, com base na narrativa do universo simbólico do catolicismo, agora apropriado pela narrativa do catolicismo popular sertanejo, e partindo de sua caracterização ambiental, sua estrutura geológico-geomorfológica e pela memória do catolicismo; dada a sua força narrativa sobre a vida de Cristo, buscando (re)viver esse tempo-espaço sagrado que não é contínuo e nem objetivo, mas de caráter transcendente. 
Pela memória coletiva do catolicismo que busca em suas trajetórias reviver o sagrado, vinculado à memória de profetas, santos e de Jesus Cristo, algumas paisagens surgem como de grande representatividade para esses sujeitos que integram esse grupo social religioso. Cassirer (2012) destaca a função da memória para a compreensão do universo cultural dos sujeitos, exercendo ela uma função simbólica, capaz não só de preservar o sistema simbólico de crenças, signos e ritos, mas de reconstruir, pelas lembranças, momentos que remetem à narrativa religiosa do grupo. É nesse sentido que uma paisagem assume valor para determinado grupo, podendo ser ressignificada, pois os elementos que a constituem corroboram com uma linguagem, uma narrativa aceita pelo grupo.

Os grandes profetas e santos do catolicismo buscavam a realização de práticas de ascetismos como forma de fugir das tentações e de se aproximarem de Deus, de conversar com Deus. Exemplos bíblicos como os de Moises, Abraão e Cristo ilustram bem esse sentido, no qual esses personagens buscavam se isolar em paisagens desoladas como os montes e os desertos, locais onde o meio ambiente áspero punha à prova o sujeito na busca por alcançar a epifania. Essa narrativa é aceita pelo grupo ao mesmo tempo em que é revivida em um novo contexto de significados, pois a concepção cultural a qual se desenvolveu o catolicismo popular sertanejo não só aceita e reconhece essa narrativa, como busca reconstruir tais momentos pelas suas próprias vivências.

Esse encontro com espaços de desolação permitia, ao profeta no passado e ao romeiro no presente, qualificarem esses locais como sagrados. Dialogando com a ideia do geógrafo humanista Yi-Fu Tuan (2013), o lugar é a pausa no movimento, a parada se estabelece enquanto lugar tornando-se centro de significados que organiza o espaço do entorno, ganhando sentido para o sujeito, sentido este centrado em uma ideia de sacralização que dota de valor simbólico aquele espaço comum. Há uma forte ligação com o sentido de topofilia para o catolicismo popular sertanejo e outras crenças religiosas para com o meio ambiente:

[...]Os encontros com Deus, tanto direta como indiretamente, por meio dos profetas, se deram em cenários de desolação, longe dos sons perturbadores dos rios e dos homens barulhentos. A paisagem despida espelhava a pureza da fé [...]. Há pessoas que evitam o meio ambiente suave e anseiam pelo deserto ou outro ambiente áspero, onde possam conhecer a dureza impiedosa da realidade e o esplendor puro. (TUAN, 2012, p.82)

A caracterização da Serra do Horto remete a essa perspectiva. Constituída de rocha cristalina onde ocorre o afloramento do granito, esse lugar foi ressignificado no imaginário religioso sertanejo, assumindo uma qualidade transcendental. Jesus realizou seu calvário na subida de um monte e sendo crucificado na parte alta. Reconhecendo essa narrativa, ressignificando-a a partir de seu universo cultural simbólico, a paisagem da Serra do Catolé é transmutada na Serra do Horto.

Os elementos que compõem a paisagem não são apenas objetos estáticos. Postos em uma narrativa, assumem novos sentidos, assim, uma árvore nunca é apenas uma árvore. A natureza não se apresenta como algo anterior à cultura e independente da história de cada povo. Em cada elemento da paisagem, na árvore, no rio, na rocha estão depositados séculos de memória (SCHAMA, 1996). Pelos sistemas de crença apropriados na narrativa, a partir de um sistema simbólico desenvolvido pela linguagem, a ressignificação pode ser realizada por um determinado grupo cultural emergindo com toda a sua força no cotidiano.

A evocação de uma memória coletiva propagada pela crença religiosa do catolicismo popular sertanejo permite ao romeiro perceber determinadas paisagens em um sentido transcendental, isto é, sagrado. Podemos assim entender como a Serra do Horto em Juazeiro do Norte ganha esse sentido de sacralidade para o devoto que busca realizar o chamado "caminho do Horto" (Figura 2), enfrentando o desafio de subir ao seu topo como forma de provação de sua fé. A força do ato não está no espaço em si, mas na linguagem que dota de significado aquela paisagem e o rito sacrifical para o grupo religioso que reconstrói a narrativa em sua vivência. 

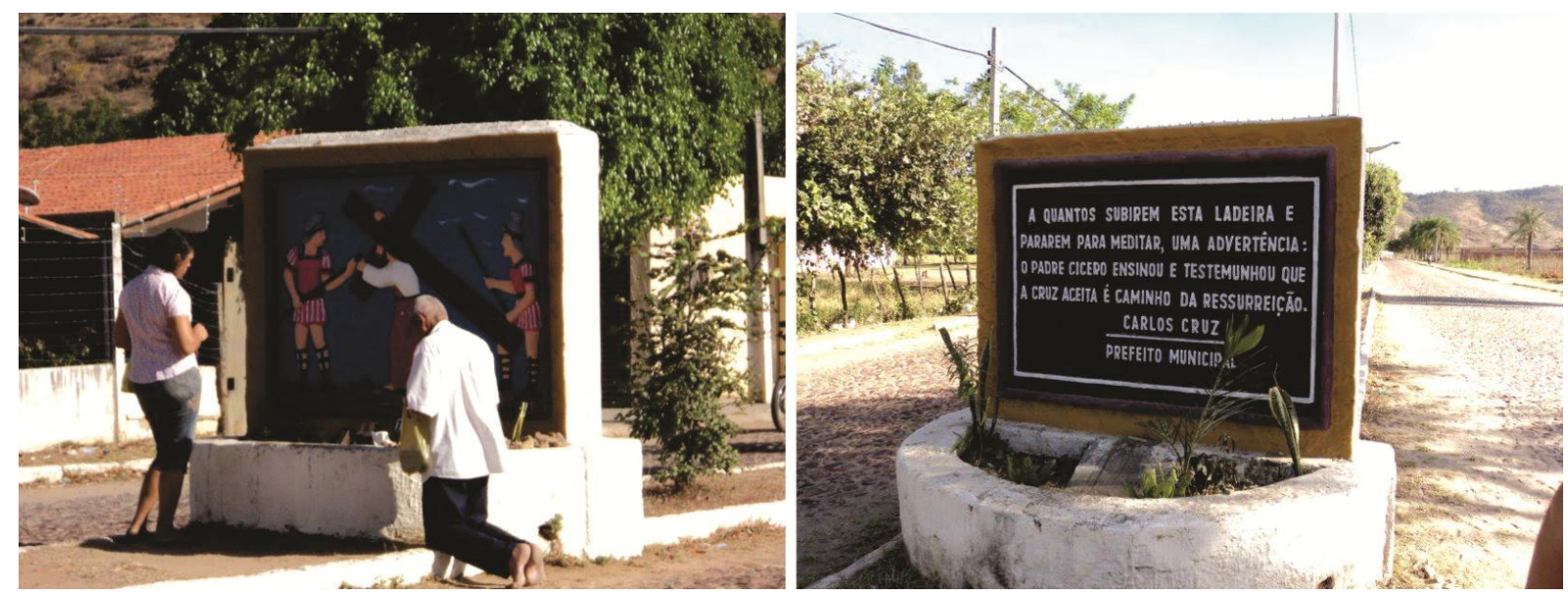

Figura 2: Caminho do Horto em Juazeiro do Norte. Fonte: Acervo do Autor, 2010.

A explanação até aqui desenvolvida ajuda a explicar o sentido que o espaço assume como sagrado para o romeiro do catolicismo popular sertanejo, um espaço espacializante de suas práticas culturais, tendo por base seu sistema simbólico religioso. Mas, é possível avançar ainda mais sob esse contexto da linguagem que transmuta o espaço pela coletividade que reconhece a trama narrativa e a aceita.

Retomando a história do Padre Cícero, este é primeiramente, juntamente com os beatos e beatas que passam a denominar a localidade de Serra do Horto, não mais a tratando como Serra do Catolé. Cabe destacar, como apontado por Braga (2014, p. 199), que:

Deve-se considerar, contudo, que a adoção desta nova nomenclatura não significou apenas o estabelecimento de novos nomes para antigos lugares e caminhos. A inclusão dessas alcunhas estava atrelada à incorporação de novos sentidos e novas práticas nas romarias de Juazeiro. E, para os romeiros, no que tange ao Horto e ao caminho que se percorria para lá chegar, isso implicava numa prática ritual de sacrifício.

Corroborando com as ideias expostas por Braga, em relação a prática do ritual de sacrifício, apresenta-se o relato de Dona Elita, romeira que se mudou para Juazeiro do Norte, no ano de 1980. Dona Elita relatou que seu marido fazia o translado de romeiros entre Maceió e Juazeiro do Norte, percurso esse que a época durava dois dias para ser percorrido. O motivo da mudança para Juazeiro do Norte deu-se por problemas de saúdes enfrentados pelo seu marido que, segundo afirmou Dona Elita, quando vinha ao Juazeiro do Norte ficava curado da enfermidade, tal questão motivou a mudança de toda a família que deixou Maceió para morar em Juazeiro do Norte, residindo na localidade da Serra do Horto.

Como diz aquele bendito: ôh, que caminho tão longe cheio de pedra e areia, valei meu padim Ciço e a mãe de Deus das Candeias. Porque é penitência, sacrifício, sofrimento, então acho que isso marca.

Bem, eu fiquei muito feliz, graças a Deus eu com quatro meses de grávida e não senti nada. Aí quando eu disse para minha doutora que vinha viajar para o Juazeiro de morada, aí ela disse: pelo amor de Deus, que vai fazer lá, a senhora vai é perder esse menino no caminho, não vá não, minha filha. $\mathrm{E}$ eu que não tinha casa e nem conhecia ninguém, só o Padre Cícero, quando subi no caminhão naquelas escadinhas não senti foi nada, eu subia, descia, fazia o fogo, as meninas ajudavam. (Entrevista cedida por Dona Elita).

A espacialização, a manifestação maior do universo religioso do catolicismo popular sertanejo, é na chegada ao lugar sagrado, a hierópolis. Entretanto, o rito também produz um ambiente cosmicizado e espacializa-se em outros ambientais no trajeto da romaria, tornando-os em lugares sagrados pelo ato do rito desde o momento inicial da partida ao Juazeiro. A fala de seu Pedro Ferreira, também é significativa nesse sentido, ao citar a vinda de seu pai em uma romaria: "Ele 'tava' 'pra' desistir da viagem que 'tava' muito doente da vista, aí o compadre dele, Avelino, disse: "não, compadre, vamos, se compadre cegar eu puxo na vara', brincando. Quando ele subiu no pau-de-arara 'pra' vim, aí ficou bom, chegou aqui 'bonzim' da vista” (Entrevista cedida por Seu Pedro).

A narrativa do sistema simbólico permite ao romeiro desenvolver essa forma devocional, ao passo que próprio percurso vai assumindo uma narrativa religiosa para o grupo, a linguagem transfigura o espaço pelo sistema simbólico religioso e, assim, os locais de parada tornam-se lugares de encontro, reforçando a fé que 
espacializa o sagrado ao reconhecerem-se em um trajeto comum. Não no aspecto material, de os sujeitos se encontrarem, mas de dividirem uma afetividade coletiva pelo sentimento religioso. Os locais de parada, de descanso, também se estabelecem como lugares sagrados, são cosmicizados no tempo sagrado dos deslocamentos para as romarias. O próprio caminhão pau-de-arara torna-se um lugar sagrado, naquele tempo sagrado da romaria, transfigura-se em santuário, como relata Dona Maria Elita:

[...] são pessoas simples [os romeiros], pobres, que passam o ano todinho juntando aquele dinheirinho pra vir cá [Juazeiro do Norte] e a gente sabe que o ônibus é muito mais caro e o pau-de-arara não. Só isso também da questão financeira, mas também do espírito da romaria, que no caminhão, o caminhão é que nem um santuário, onde eles rezam o ofício, cantam seus benditos, reza a noite todinha. (Entrevista cedida por Dona Elita).

No aspecto que Braga nos apresenta da adoção de novas toponímias para os lugares, marcadas pelas práticas devocionais dos romeiros, fez-se presente nessa crença da "Terra sem males", reforçando o aspecto simbólico devocional do catolicismo popular sertanejo, o ato sacrifical iniciava-se na saída do local de origem.

Na paisagem da Serra do Horto, uma materialidade marca o lugar. Padre Cícero construiu um grande casarão (Figura 3) no alto da serra e passou a residir ali por alguns anos. Consta na tradição oral que, no período de construção do casarão, beatos, ao se deslocarem junto com os construtores no percurso do início da subida da serra até o topo onde se fixou a fundação da casa, pregavam as histórias bíblicas, realizavam a narrativa simbólica (a ideia da formação do catolicismo popular sertanejo exercida pela figura da beata e do beato) utilizando-se de elementos presentes na paisagem da região. Assim, o rio que corre no início da subida da serra (Rio Salgadinho) é ressignificado no Rio Jordão; já em outro itinerário da subida do Horto uma rocha cravada num monte se transfigurava no Monte Sinai; e, o próprio trajeto até o alto da serra era ressignificado como o calvário percorrido por Cristo até sua crucificação e morte. Esses elementos da paisagem se constituíram da sacralidade pela narrativa efetuada e reconhecida pela coletividade do catolicismo popular sertanejo. Como uma "Terra sem Males" onde o próprio sangue de Cristo foi derramado, pelo ato hierofânico, aquele espaço transmutou-se na "Jerusalém Sertaneja".

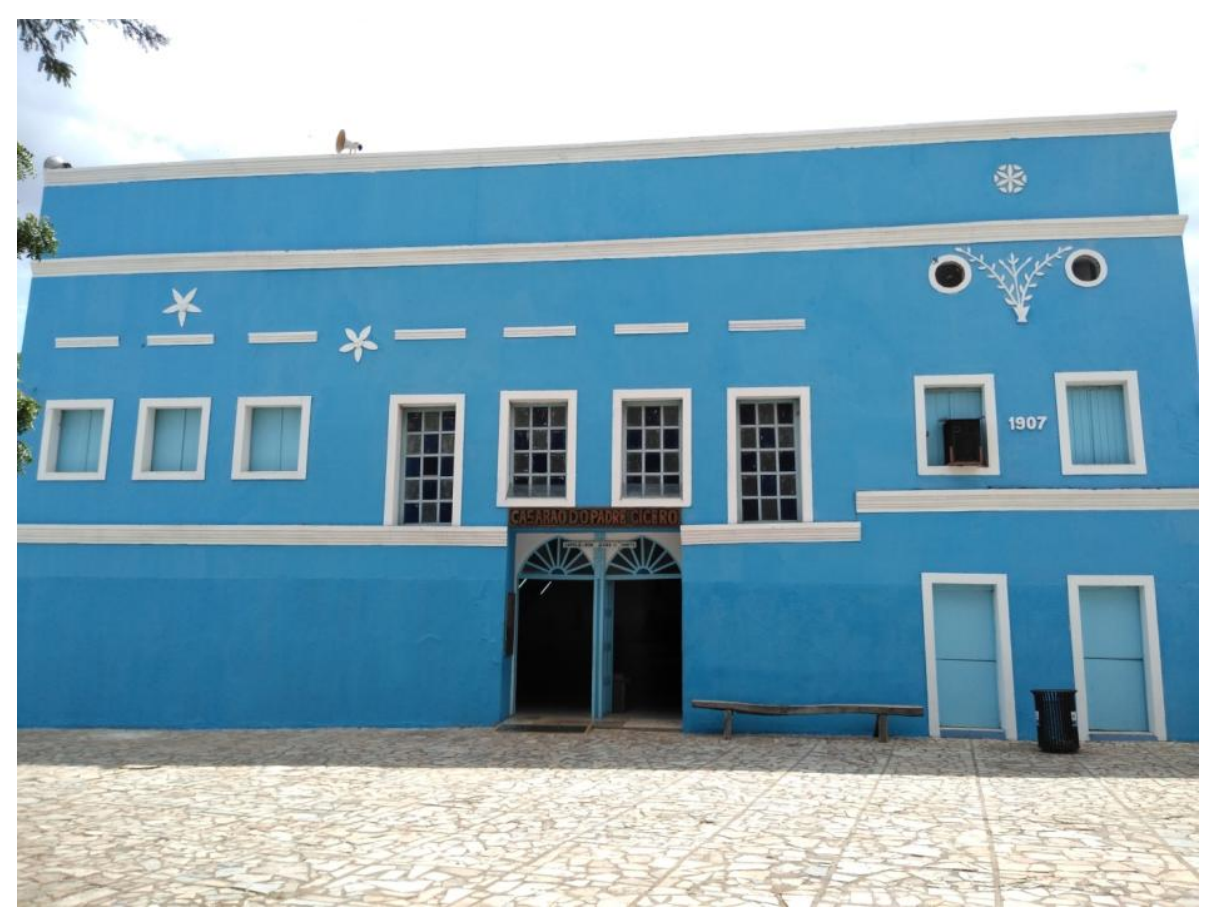

Figura 3: Casarão do Horto. Fonte: Acervo do autor, 2018.

Os elementos físicos presentes na paisagem natural do local permitiram a reconstituição da história da tradição cristã, o que fez com que os romeiros daquele lugar passassem a associar a cidade de Juazeiro como "Jerusalém Sertaneja". O espaço profano é, assim, convertido em espaço sagrado, onde o processo simbólico reflete as características emocionais associadas às características físicas (ROSENDAHL, 2009).

Com a fama de "Santo dos Sertões" que o padre passou a possuir pelos seus feitos extraordinários, os quais o povo sertanejo associava a ele, fez com que Juazeiro do Norte fosse vista pelos seus fiéis romeiros 
como uma "Terra sem Males", a "Jerusalém Sertaneja", a paisagem local que permitia recordar as passagens bíblicas.

Apropriando-se do sistema simbólico do catolicismo romano, os romeiros de Juazeiro que passaram a habitar a cidade já emancipada (1911) viam o perigo de ela sofrer destino semelhante ao de Canudos. Com esse reconhecimento da trama narrativa aceita pela coletividade e pela qual o lugar foi transfigurado em lugar sagrado, não haveria a necessidade de reconhecimento da oficialidade da Igreja para aquele lugar, uma vez que o que valia eram as experiências vividas, acreditando-se ter chegado à "Terra sem Males", o que fez com que os romeiros do catolicismo popular sertanejo lutassem pela defesa da "Jerusalém Sertaneja".

Recordando as ideias de Halbwachs (2003, pp. 182-183) sobre a memória coletiva dos grupos religiosos, apontamos que:

\begin{abstract}
Não há nada surpreendente em que as lembranças de um grupo religioso lhes sejam trazidas pela visão de determinados lugares, determinadas localizações ou certas disposições dos objetos. Para essas sociedades, a separação essencial entre o mundo sagrado e mundo profano se realiza materialmente no espaço. Quando entra numa igreja, num cemitério, num lugar santificado, o fiel sabe que ali voltará a encontrar um estado de espírito que já experimentou e, com outros crentes, reconstituirá, ao mesmo tempo que uma comunidade visível, um pensamento e lembranças comuns - as mesmas que se formaram e foram sustentadas em épocas anteriores, nesse mesmo lugar.
\end{abstract}

Diferenciamos os sujeitos do catolicismo popular sertanejo dos demais crentes do catolicismo romanizado, pois estes não necessitam que suas práticas sejam como aquelas dos dogmas e dos ritos da Igreja Romana, realizando suas práticas religiosas ligando-as às experiências vividas pelos seus antepassados, no modo de vida que essa sociedade foi forjada e na forma como sua cultura foi sendo transfigurada, essa "experiência pode ser direta e íntima, ou pode ser indireta e conceitual, mediada por símbolos" (TUAN, 2013, p. 14). Dito isso, suas práticas devocionais ora se encontram, ora se confrontam com os dogmas e os ritos existentes do catolicismo romanizado. Mas não necessitam do reconhecimento por parte da Igreja Católica Romana. A apropriação do universo simbólico do catolicismo e sua reconstituição no grupo pelas questões históricas coloniais permitem reconhecer em sua coletividade essa forma simbólica. Nesse sentido, Gil Filho (2012, p. 80), ao citar Cassirer, define que: "[...] A explicação do mundo da religião não deve partir do sistema teológico ou metafísico ao qual está relacionado, mas sim de sua forma".

Para este grupo religioso, o Padre Cícero como "santo dos sertões" chega ao status dos santos canonizados pela Igreja Católica. O padre, ao passar a residir no alto da Serra do Horto, isola-se como os profetas faziam. Em seu antigo Casarão, hoje transformado no Museu Vivo do Padre Cícero, romeiros que se dirigem à Juazeiro do Norte realizam a visita ao local e deixam seus ex-votos (Figura 4) como a materialização da graça alcançadas (cura de uma doença, conquista de um bem material - carro, casas, diplomas, cd's, títulos de futebol, etc.). $\mathrm{O}$ ato da entrega do ex-voto está ligado a todo o roteiro devocional realizado pelo romeiro, dispondo-o em uma parte específica da casa, onde o cenário retrata uma cena na qual o Padre Cícero está de joelho "intercedendo pelo seus romeiros". Ainda há no local outras cenas retratando o cotidiano do Padre Cícero. A concepção da sacralidade do lugar está ligada ao universo simbólico do romeiro.

A paisagem em que se transformou o Casarão do Horto (o Museu Vivo do Padre Cícero) constitui-se de um documento materializado das práticas e crenças devocionais existentes no grupo do catolicismo popular sertanejo. Fotografias de ciganos e traços africanos e dos nativos nos ex-votos de madeira afirmam para o processo de constituição do universo simbólico cultural religioso ligado ao catolicismo popular sertanejo.

Outro espaço que tem grande relevância para o romeiro do catolicismo popular sertanejo que vai à Juazeiro do Norte é o lugar conhecido como Santo Sepulcro (Figura 5), paisagem que reporta às narrativas descritas pelas passagens bíblicas. Esse local, como relatado pela tradição oral de muitos romeiros e de pessoas que tiveram seus pais e avós que conviveram com o Padre Cícero, conta que era o local para onde o Padre se retirava para realizar suas orações e seus encontros com Deus. Em vista disso, ao envolver esse espaço com um significado, ele se torna um lugar sagrado, um itinerário simbólico da Serra do Horto. 


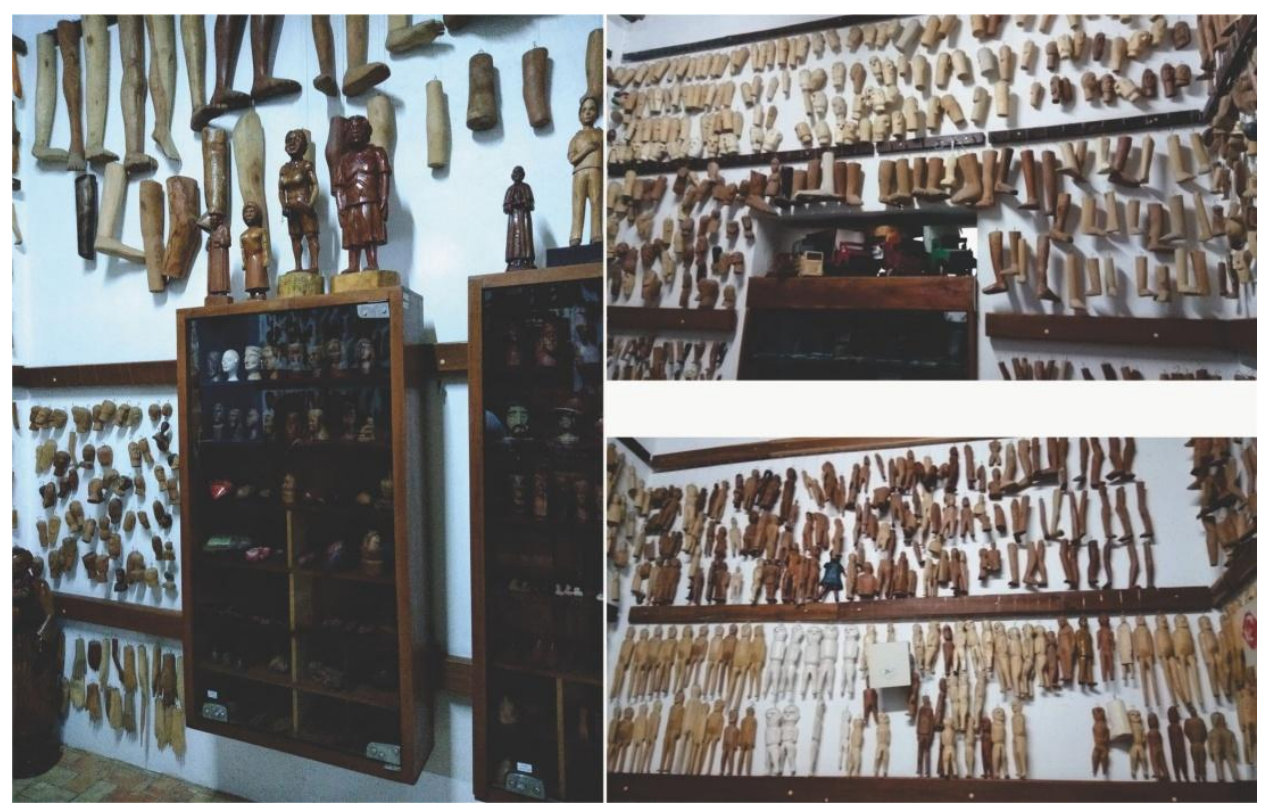

Figura 4: Sala dos Ex-votos. Fonte: Acervo do autor, 2018.
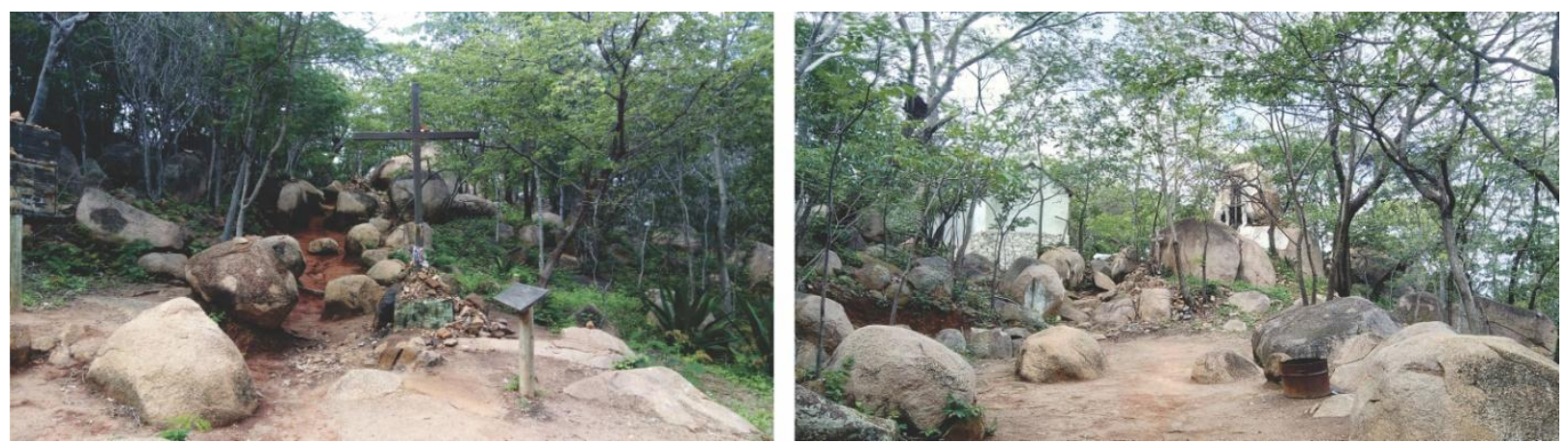

Figura 5: Santo Sepulcro. Fonte: Acervo do autor, 2018.

Pensando também na contextualização que fizemos em relação à constituição cultural do sujeito sertanejo inserido no período do colonialismo, lembramos novamente o papel exercido pelos beatos, corroborando com a defesa Barros (2014) quando fala sobre os líderes intelectuais do movimento, dotando de maior significado na forma cultural simbólica religiosa os beatos sepultados no local.

O significado que reveste esse lugar simbólico para o catolicismo popular sertanejo não está simplesmente ligado à memória do Padre Cícero, mas aos próprios acontecimentos vividos por sujeitos que passaram a habitar em Juazeiro, fugindo das desgraças que assolavam o povo no final do século XIX e início do século XX.

Oliveira (1974) relata que, no ano de 1889 , o povo volta a temer o acontecimento de mais uma grave seca como a que acontecera no ano de 1877, já se espalhando o temor de viver mais uma calamidade. O Padre Cícero e outros sacerdotes se uniram em oração e prometeram a construção de uma igreja devotada ao Sagrado Coração de Jesus se o povo fosse poupado de uma nova catástrofe. As chuvas vieram e o povo se viu livre de outra seca e a igreja prometida seria construída na Serra do Horto, algo que não veio a se cumprir. O Padre chegou a dar início, junto aos seus romeiros, à construção da igreja, mas fora impedido pela Igreja, dados os acontecimentos ligados ao "milagre da hóstia" e a suspensão das suas ordens. Assim, se reveste de simbolismo, sacralidade e de uma cultura a qual os sujeitos se reconhecem que são pertencentes a esse grupo social religioso.

Outro fato que traz significado aos sujeitos do catolicismo popular sertanejo e para a Serra do Horto era o percurso realizado pelos romeiros que chegavam à Juazeiro e subiam a serra para pedir a benção do Padre Cícero - após sua morte, este ritual permaneceu na memória dos romeiros de Juazeiro do Norte e, até os dias de hoje, é praticada por grupo de romeiros como uma forma de manter viva a memória do Padre Cícero e as práticas ritualísticas dos seus antepassados. O Padre Cícero é tido no sistema simbólico do catolicismo popular sertanejo como um símbolo, o "Messias" o "salvador" que apareceu para salvar seu povo. Na trama que se constrói após a morte do "padim" é que ele não morreu, mas foi visitar Nossa Senhora para interceder 
pelo povo e irá novamente ressurgir para os romeiros na Serra do Horto. A narrativa da concepção bíblica do Catolicismo Romano novamente é reapropriada e reinterpretada à luz da cultura dos sujeitos pertencentes ao catolicismo popular sertanejo que lhe dão um novo valor simbólico.

Com a construção do monumento ao Padre Cícero, uma estátua de 27 metros (Figura 6). A prática da subida ao Horto permanece e o pedido da benção ao "padim ciço" também. Como os próprios romeiros dizem e que foi reproduzido pela música de Luiz Gonzaga e João Silva (Viva meu Padim): "olha lá no alto do Horto, ele tá vivo, padre não tá morto". O material reforça o conteúdo simbólico do universo religioso do romeiro.

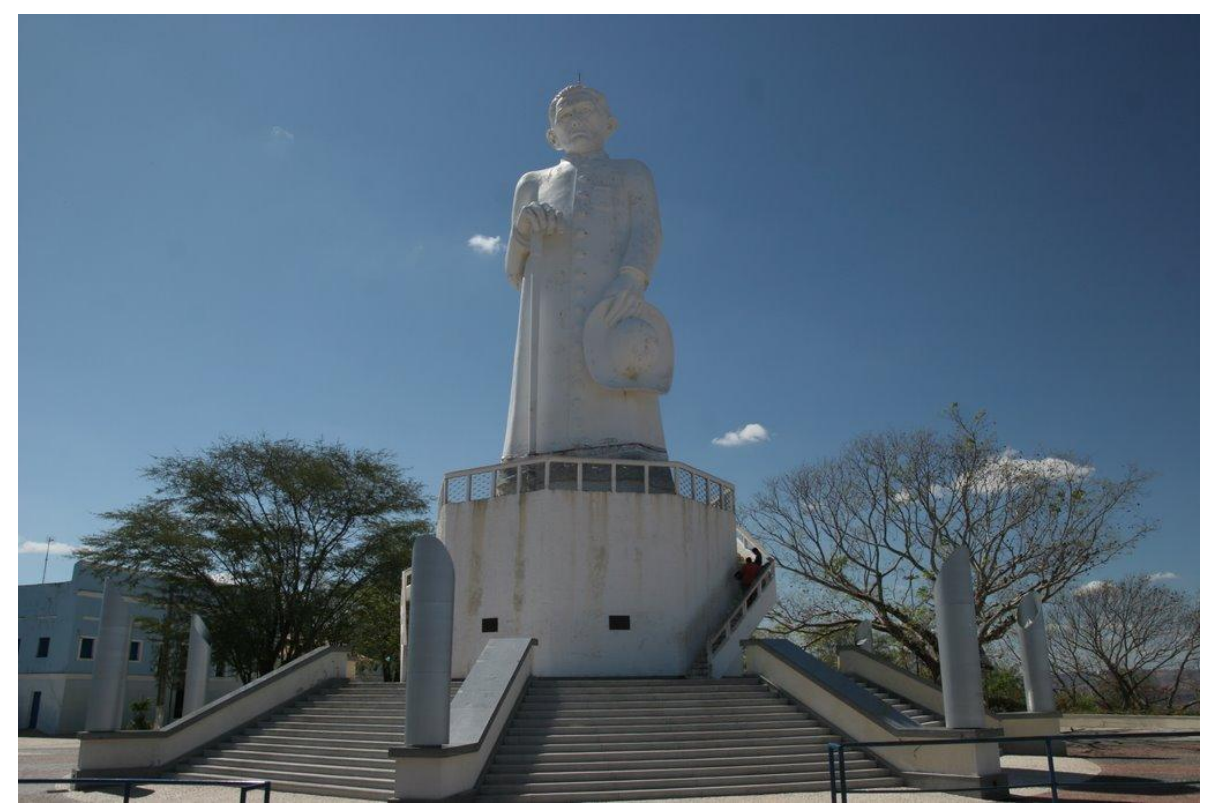

Figura 6: Monumento do Pe. Cícero. Fonte: Acervo do autor, 2017.

Essas questões que citamos revestem a paisagem da Serra do Horto da cultura e simbolismo do grupo religioso, evocando lembranças e sacralizando esse espaço transfigurado pelas crenças, pelos ritos e pelo sistema simbólico dos crentes sertanejos e transfigurando-se em um lugar sagrado para eles. Nesse sentido, concordamos com as palavras de Costa (2008, p. 151), argumentando que: "Essa relação entre o indivíduo e a paisagem é, portanto, mediatizada por uma rede simbólica cuja materialidade traz também o imaterial, algo visível que mostra o invisível, um gesto que significa um valor".

A força simbólica que a Serra do Horto apresenta para o universo religioso do romeiro, reforçando a narrativa simbólica interiorizada pela coletividade dos romeiros, encontra na paisagem deste lugar elementos que são ressignificados e reforçam a crença da "Terra sem Males", transmutada na "Jerusalém Sertaneja", dado pela forma simbólica assumida pelo grupo religioso do catolicismo popular sertanejo.

Em períodos de romaria, principalmente entre os meses de setembro a março, os elementos físicos da paisagem recordam lembranças que trazem vários significados que os símbolos presentes na paisagem remetem aos romeiros e estes percebem aquele espaço como sacralizado, como um lugar sagrado. Torna-se lugar, pois, a afetividade daquele local é realizada pelo sujeito, há um sentido naquele espaço, de modo que se diferencia do espaço comum em volta. A pausa permite essas recordações.

Novamente, corroboramos com as afirmações de Costa (2008, p. 154) sobre a paisagem: "A paisagem reveste-se de elementos nostálgicos que invadem sua essência e permitem se contaminar por outras memórias, outras recordações, outros lugares da memória e evocam fragmentos do passado que cristaliza em um imaginário".

O revestimento nostálgico que invade a essência faz com que o sujeito se reconheça como parte de uma cultura, de um grupo religioso que reconhece a sacralidade presente naquele local que a diferencia do espaço profano em volta. O revestimento de sacralidade está ligado ao sistema simbólico do catolicismo popular sertanejo, no qual a figura do padre Cícero é para os romeiros de Juazeiro do Norte o "Santo dos Sertões", assim, tudo que está ligado a ele e à sua memória reveste o lugar de sacralidade e transforma a paisagem pelo simbólico que passa a remeter para esses sujeitos, se oferecendo para o corpo e percepção desses sujeitos que passam a considerá-la como centro do mundo (MERLEAU-PONTY, 2011), ganhando um sentido e transformando em lugar sacralizado. 
Ao realizar nossa análise de campo no Horto, atentamos para as conversas entre alguns romeiros que lá se encontravam e relatavam qual o sentido que aquele lugar possui para eles. Um primeiro senhor, que estava sentado em um espaço coberto por detrás da estátua do Padre Cícero falava: "aqui é um lugar bom, de paz, do meu padim. Acalma nossa alma". Uma outra senhora relata: "vir ao Juazeiro, vir ao Horto é se encontrar com Padre Cícero e Nossa Senhora das Dores, pagar nossas promessas, rezar pela nossa família, pela saúde". Fica claro que, nessas falas ligadas ao contexto cultural e a narrativa aceita pelo catolicismo popular sertanejo, o lugar é revestido de sacralidade.

Vários ritos cercam a subida do Horto, o próprio local e o Santo Sepulcro. Atos como o de colocar uma pedra em cima de uma árvore apresentam-se como forma de deixar seu pecado após o trajeto da purificação, através do ritual de sacrifício da subida ao Horto. Esses contextos podem estar ligados à justaposição dos sistemas simbólicos que conformaram o catolicismo popular sertanejo a partir do contexto histórico do colonialismo. Sobre isso, assim discorre Braga (2014, p. 201):

[...] percorrer o caminho do Horto é atravessar um percurso através do qual o romeiro - por meios de determinados atos devocionais - vai se consagrando. Ele vai sendo consumido em suas forças físicas, mas ao mesmo tempo adquirindo um novo estado moral. Vai se elevando.

Outros rituais são realizados durante a caminhada, assim como após a chegada. A parada nas estações da via sacra (que relembra a via crucis de Cristo) para oração, a pedra do joelho, ao que conta uma romeira: "foi o joelho de Nossa Senhora que está gravado na pedra, a gente põe nosso joelho para aliviar o cansaço e continuar a subida"; na chegada ao topo, alguns romeiros ainda sobem as escadarias de joelhos para pagar promessas e ainda dão as três voltas no entorno da bengala do monumento do Padre Cícero, além da oração em agradecimento pela graça alcançada; a visita ao Museu Vivo do Padre Cícero no Casarão onde residiu; a ida ao Santo Sepulcro e as várias outras simbologias existentes na paisagem desse local. Este é um pouco do roteiro devocional realizado pelo romeiro e marca o processo de espacialização do universo simbólico do catolicismo popular sertanejo na cidade de Juazeiro do Norte.

Assim a paisagem apresenta-se como um documento possível de ser analisado pela trama narrativa do sagrado que se espacializa da cultura e do sentido que ela tem para determinados grupos sociais que captam na paisagem significados e projetam seu mundo simbólico, remetendo a significados dentro de diferentes contextos e, no caso do Horto, a sacralidade que esse lugar assumiu para o catolicismo popular sertanejo.

\section{Considerações finais}

Ao analisar esses espaços sagrados ligados ao sistema simbólico do catolicismo popular sertanejo em Juazeiro do Norte, o que se nota é a espacialização das práticas rituais, devocionais do sistema de crença, a materialização dos símbolos e signos, reforçando o sistema simbólico religioso ao qual pertencem os sujeitos do catolicismo popular sertanejo.

Podemos afirmar para uma identidade religiosa existente entre vários sujeitos, que se reconhecem em uma narrativa comum a estes, em uma coletividade, assim pode ser condicionada a uma determinada temporalidade e espacialidade sagrada. A materialidade da religião e as representações espaciais realizadas pelos sujeitos, nos permitem apresentar a identidade do grupo religioso, no caso aqui estudado, o catolicismo popular sertanejo.

Desta forma, o sistema religioso é permeado por uma linguagem que é transmitida pelo grupo, no qual estrutura outro sistema simbólico, aqui temos a religião do catolicismo popular sertanejo. Nesse sentido, ao tratar da identidade religiosa, Gil Filho (2008, p. 83) aponta que "[...] ao destacarmos a identidade religiosa, também estamos diante de uma construção que remete à materialidade histórica, à memória coletiva, à espacialidade da própria revelação religiosa processada em determinada cultura".

É nesse contexto que defendemos a concepção de memória hierofânica. Quando partimos da compreensão que estrutura o grupo, a partir da sua forma simbólica, inserida no contexto cultural ao qual foi constituída, este grupo produz uma coerência, utilizando da forma simbólica da linguagem para construir seu sistema cultural, no qual a religião expressa-se como uma forma simbólica de uma coletividade de sujeitos, pertencentes a um mesmo grupo cultural. A narrativa que é produzida, permite o reconhecimento do sagrado a coletividade, dado ao sistema cultural comum do grupo.

As formas simbólicas religiosas, desta forma, ao serem reconhecidas pela coletividade do grupo religioso, aqui entendido a partir do catolicismo popular sertanejo, vão espacializar suas práticas religiosas, ritos, 
signos, crenças em determinados espaços e tempos sagrados, que são reconhecidos por essa coletividade. O espaço sagrado é produzido pela consciência religiosa concreta, sendo assim, não se deve realizar a separação entre a posição e o conteúdo, este último é parte da consciência do vivido plenamente sensível (GIL FILHO, 2008).

Uma coletividade, um grupo cultural, para resistir e sustentar seu sistema simbólico, precisa fazer com que seus sujeitos se reconheçam pertencentes a essa realidade cultural, assim é onde participa a memória, não entendida aqui apenas pela oralidade dos sujeitos que participam do mesmo grupo, a linguagem também compõe o sistema simbólico, mais a espacialização das práticas culturais, aqui no nosso caso a religião, dá suporte a permanência e reconhecimento dos sujeitos a aquele grupo religioso. Desta forma, aos espaços e lugares sagrados, no qual ocorrem as espacializações das práticas religiosas do grupo, apresentam-se como documentos da narrativa que compõem a memória hierofânica da qual o grupo se reconhece. Esse é o caso aqui estudado, com base no catolicismo popular sertanejo.

\section{Agradecimentos}

À CAPES (Coordenação de Aperfeiçoamento de Pessoal de Nível Superior) pelo apoio, através de bolsa de doutoramento, para a realização da pesquisa de doutorado.

\section{Notas}

Parte das discussões teóricos, sobre memória hierofânica, apresentadas nesse artigo, também foram realizadas no trabalho intitulado "JUAZEIRO DO NORTE E A ESPACIALIZAÇÃO DO CATOLISCISMO POPULAR SERTANEJO". No entanto, não se trata do mesmo trabalho, abordando um recorte espacial diferente do texto citado.

\section{Referências}

BARROS, L. O. C. Juazeiro do Padre Cícero: a terra da Mãe de Deus. 3. ed. Fortaleza: IMEPH, 2014.

BRAGA, A. M. C. A subida do Horto: ritual e topografia religiosa nas romarias de Juazeiro do Norte, Ceará, Brasil. Revista Debates do NER.; ano 15, n. 25, 197-214, 2014. DOI: 10.22456/1982-8136.49728.

CASSIRER, E. Ensaio sobre o homem: introdução a uma filosofia da cultura humana. 2. ed. São Paulo: Editora WMF Martins Fontes, 2012.

CASSIRER, E. A filosofia das formas simbólicas: o pensamento mítico. II. São Paulo: Martins Fontes, 2004.

COSTA, O. J. L. Canindé e Quixadá: construção e representação de dois lugares sagrados no sertão do Ceará. 2011. 216 f. Tese (Doutorado em Geografia). Instituto de Geociências, Universidade Federal do Rio de Janeiro, Rio de Janeiro, 2011.

COSTA, O. J. L. Memória e paisagem: em busca do simbólico dos lugares. Espaço e Cultura.; Edição comemorativa 1993-2008, 149-156, 2008. DOI: 10.12957/espacoecultura.2008.6143.

DURKHEIM, É. As formas elementares de vida religiosa: o sistema totêmico na Austrália. 3. ed. São Paulo: Paulus, 2008.

GIL FILHO, S. F. Espacialidades de conformação simbólica em geografia da religião: um ensaio epistemológico. Espaço e Cultura.; n. 32, 78-90, 2012. Disponível em: <http://www.epublicacoes.uerj.br/index.php/espacoecultura/article/view/6977>.

GIL FILHO, S. F. Espaço sagrado: estudos em geografia da religião. Curitiba: IBPEX, 2008.

GIL FILHO, S. F. Geografia da religião: reconstruções teóricas sob o idealismo crítico. In: KOZEL, Salete; SILVA, José da Costa; GIL FILHO, Sylvio Fausto (orgs). Da percepção e cognição à representação: reconstruções teóricas da geografia cultural e humanista. São Paulo: Terceira Imagem, 2007. p. 207-222. 
HALBWACHS, M. A memória coletiva. São Paulo: Centauro, 2003.

MERLEAU-PONTY, M. Fenomenologia da percepção. 4. ed. São Paulo: Martins Fontes, 2011.

OLIVEIRA, A. X. O Padre Cícero que eu conheci - verdadeira história de Juazeiro do Norte. Fortaleza: Editora Henriqueta Galeno, 1974.

OLIVEIRA, P. W. A. Juazeiro do Norte e a espacialização do catolicismo popular sertanejo. In: SILVA, J. F. da S. et. al. (orgs.). Patrimônio e Práticas Culturais: perspectivas transdisciplinares da patrimonialização e dos saberes-fazeres populares. Fortaleza: DIN.CE, 2021. p. 49-68.

ROSENDAHL, Z. Hierópolis: o sagrado e o profano. 2. ed. Rio de Janeiro: Eduerj, 2009.

SCHAMA, S. Paisagem e memória. São Paulo: Companhia das Letras; 2009.

TUAN, Y. F. Espaço e lugar: a perspectiva da experiência. Londrina: Eduel, 2013.

TUAN, Y. F. Topofilia: um estudo da percepção, atitudes e valores do meio ambiente. Londrina: Eduel, 2012.

(1) (2) (2) 